\title{
Medicinal Orchids of Nepal: Are They Well Protected?
}

\author{
K.P. Acharya ${ }^{1 *}$ and M.B. Rokaya ${ }^{2,3}$ \\ ${ }^{1}$ Institute of Biology, Norwegian University of Science and Technology, 7491, Trondheim, Norway \\ ${ }^{2}$ Department of Ecology, Faculty of Sciences, Charles University, Viničná 7, CZ- 12844 Praha 2, Czech \\ Republic \\ ${ }^{3}$ Institute of Botany, Academy of Sciences of the Czech Republic, Zámek 1, CZ-252 43 Prìhonice, Czech \\ Republic \\ *E-mail: acharya.kamal@gmail.com
}

Received: 10.09.2009, Accepted: 28.11.2010

\begin{abstract}
This paper aims to explore distribution pattern of orchids used for medicinal purpose and their conservation aspect. We compiled information on 82 species of orchids which are used as herbal medicine. Maximum richness of medicinal orchids was observed at an elevation of $1700 \mathrm{msl}$ but, the maximum numbers of protected areas are located at an elevation of 3000 to $3500 \mathrm{~ms}$. There is a negative correlation between number of protected areas and medicinal orchid species richness mentioning that the protected areas are less synchronized with med icinal orchids of Nepal.
\end{abstract}

Key words: Elevation gradient, Generalized Additive Models, medicinal orchid, species richness

\section{Introduction}

The orchid family is regarded as one of the largest, most diverse and distinctive families in the flowering plant kingdom with estimates of about 20,000 to 35,000 species in the world (Dressler, 1993). They are found in wide array of ecological conditions, except in marine environments and habitats with extreme cold throughout the year. Environmental conditions associated with altitude exert a large influence on orchid species composition and their distribution (Jacquemyn et al., 2005). The plants are terrestrial, epiphytic, lithophytic and saprophytic in habitat.

In Nepal, nearly 388 orchid's species within 99 genera are reported (Acharya, 2008). Orchids are well known not only for their ornamental value, but also for their uses in herbal medicine (Sumner, 2000). The use of orchids as medicine has a very long history and the Chinese were the first to use them as herbal medicine (Bulpitt, 2005). The presence of phytochemicals such as alkaloids, flavonoids, glycosides have made orchids valuable as medicine (Pengelly, 2004).

In Nepal, studies on orchids are mainly focused on their documentation (Shakya and Chaudhary, 1999; Bajracharya et al., 2003; Subedi, 2003; Rajbhandari and Dahal, 2004; Shakya and Shrestha, 2007; Shrestha et al., 2007) and on its medicinal uses (Shreshta, 2000; Vaidya et al., 2000) but there is lack of quantitative study on their distribution pattern. It is necessary to know distribution patterns along the 
elevational gradients, because information on altitudinal species richness patterns can be highly instrumental for proper management and conservation of species (Grytnes, 2003). Orchid species are facing the greatest threat due to human encroachment, habitat loss, forest destruction and degradation (Rajbhandari et al., 2000; Winkel, 2006). So, we have made an attempt to reveal the distribution pattern of medicinal orchids from Nepal. Specifically, we have tried to answer following questions: (a) what is the distribution pattern of medicinal orchid species along an elevational gradient in Nepal? and (b) are these orchids well conserved in existing protected areas?

\section{Materials and methods Study area}

Nepal $\left(26^{\circ} 22^{\prime}-30^{\circ} 27^{\prime} \mathrm{N}\right.$ and $80^{\circ} 40^{\prime}-$ $88^{\circ} 12^{\prime} \mathrm{E}$ ), in central Himalaya consists of five east-west running ranges: Terai, Siwaliks, Mahabharat, High mountains and High Himalaya (LRMP, 1986). Within this short distance, the elevation ranges from about 60 to $8848 \mathrm{~m}$ (highest peak of the world) and comprises tropical to alpine climatic zones.

Nepal has a wide range of climatic conditions. However, the climatic conditions can be broadly divided into two types: dry winter period and wet summer period. The climatic condition is dominated by precipitation of the summer monsoon starting from south, Bay of Bengal. The amount and distribution of precipitation, the duration and altitudes of cloudiness varies considerably in different parts. The amount of rainfall gradually decreases from east to west, but increases from the plain to certain elevations between 800 to $2000 \mathrm{msl}$ to the north and then again decreases.

\section{Data source and interpolation}

We collected information on elevational ranges of orchids used for medicinal purposes from various literatures (Jha et al., 1996; Rajbhandari et al., 2000; Sharma, 2000; Shrestha, 2000; Vaidya et al., 2000; Lama et al., 2001; Rajbhandari, 2001; Manandhar, 2002; Rokaya, 2002; Subedi, 2003; IUCN, 2004; Baral and Khurmi; 2006; DPR, 2007). The medicinal orchids are distributed from 100 to $4800 \mathrm{msl}$. So, to examine the relationship between species richness and elevation, the total elevation gradients between $100 \mathrm{~m}$ and $4800 \mathrm{~m}$ were divided into 48 bands of $100 \mathrm{~m}$ elevation each. The number of species present in each elevation band was estimated by the interpolation. A species was defined as being present in every $100 \mathrm{~m}$ interval between its upper and lower elevation limits. For example, Dactylorhiza hatagirea with its elevation limit between $2800 \mathrm{~m}$ and $4000 \mathrm{~m}$ was assumed to be present in each elevation band of 2800, 2900, 3000, 3100, 3200 , and so on upto $4000 \mathrm{~m}$ (Acharya et al., 2009). We used the term species richness for the total number of medicinal orchid species present in each $100 \mathrm{~m}$ elevation. To find the number of protected areas (national parks, wildlife reserves, conservation areas, and hunting reserves) occurring in each $100 \mathrm{~m}$ elevation band, the altitudinal range of each protected areas was taken from GoN/MFSC (2009).

\section{Statistical analysis}

We used Generalized Additive Models (GAMs) (Hastie and Tibshirani, 1990) with 
up to four degrees of freedom to explore the pattern of species richness with elevation. We used elevation as an explanatory variable and species richness and number of protected areas as a response variable. Species richness data were considered to follow a Poisson distribution as it is count (discrete) data (Crawley, 2005) which requires a logarithmic link. However, because of overdispersion, a quasi-Poisson model was used (Crawley, 2005) with a logarithmic link. We used an f-test to check the significance of models because this is more robust when there is overdispersion (Crawley, 2005). We used $\mathrm{R}_{2.8 .1}$ (R Development Core Team, 2008) for the regression analysis and graphical representations.

\section{Results and discussion}

\section{Life forms and distribution of medicinal} orchids in Nepal

In total 82 species belonging to 40 genera of orchid species are used for medicinal purposes in Nepal. Out of which, 33 are terrestrial (40\%), 43 are epiphytes (53\%) and six are of mixed habitat (7\%) (Fig. 1, Append. I). Center Nepal harbours highest number of species (69 species i.e., 43\%) followed by east Nepal (58 species i.e., $36 \%$ ) and west Nepal (33 species i.e., 21\%) (Fig. 2). Among them, six species are recorded only from east Nepal, eight species only from center Nepal and three species only form west Nepal and rest of the species are recorded from wider distributional ranges. Maximum richness of total medicinal orchid species richness is observed at an elevation of $1700 \mathrm{msl}$ (Fig. 3a).

We found hump-shaped patterns of medicinal orchid species richness along the

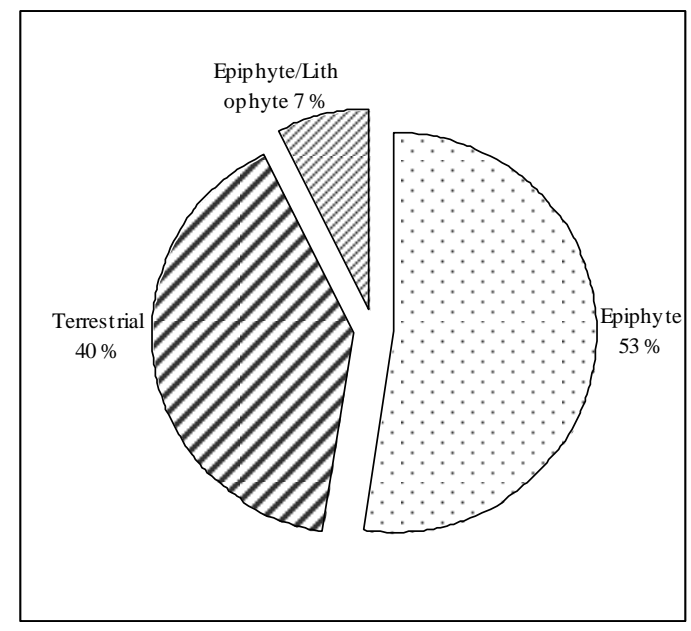

Figure 1. Different life forms of medicinal orchids of Nepal.

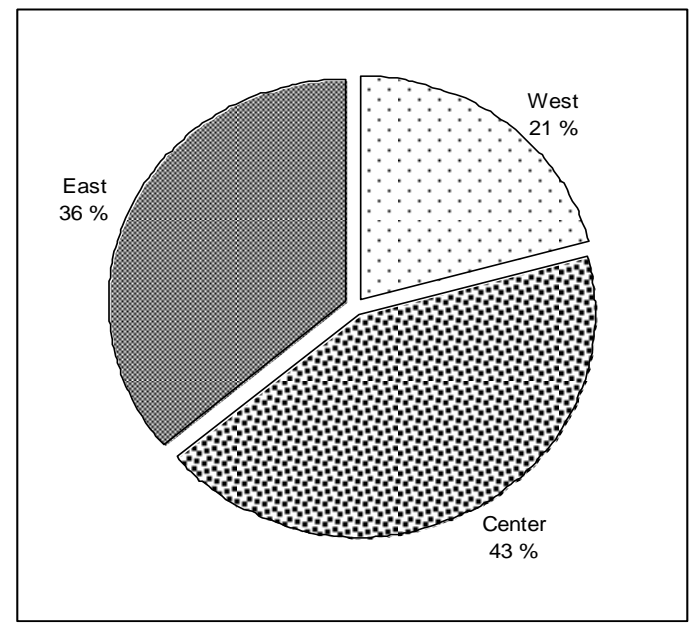

Figure 2. Distribution of medicinal orchids in east, center and west Nepal.

elevation gradient in Nepal Himalaya. This study supports the findings made by Malla and Shakya (1999) that maximum numbers of medicinal plants are found within the elevation of 1000-2000 msl. However, it differs from the findings made by Acharya et al. (2009) that maximum richness of medicinal plants are found at an elevation of 
1100 msl. More than thirty different hypotheses have been proposed as possible explanations to explain these patterns. However, climatic variables possibly could explain the best for the patterns of distribution of medicinal orchids in elevational gradient of Nepal. Because maximum richness of species occurs at the locations with maximum rainfall and optimum energy conditions are available (Odland and Birks, 1999). The maximum richness of medicinal orchids at an elevation of $1700 \mathrm{msl}$ might be due to the optimum water energy dynamics (Bhattarai and Vetaas, 2003). West Nepal is the driest part of Nepal and the water-energy dynamics model explained by O'Brien (1998) could also explain about species richness of orchid being highest in centre or east than in west Nepal. More over, central Nepal is the overlap of eastern and western floral elements in central Nepal and thus there are more species in the centre than other regions of Nepal.

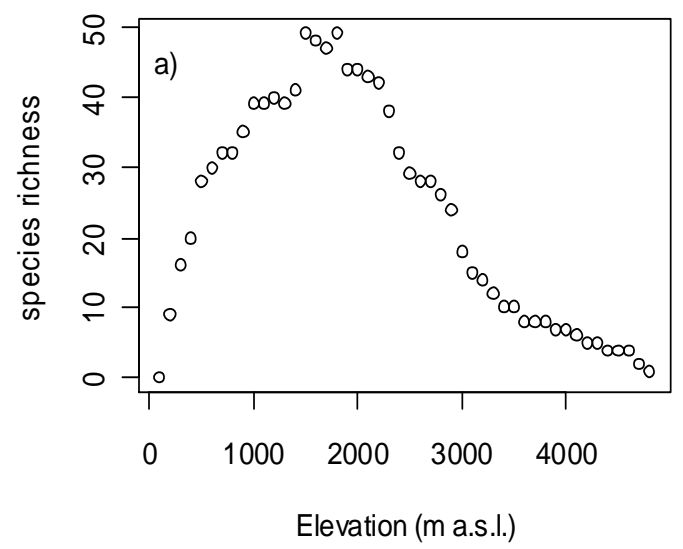

Figure 3a. Distribution of medicinal orchid species with elevation in Nepal.

Mid elevation peak in species richness may be the result of large scale mass effect (Shmida and Wilson, 1985).
Mid elevation receives inputs from both the lower elevations and higher elevations. So, mass effect or source sink dynamics may be important to influence variation in species richness within an elevation gradient.

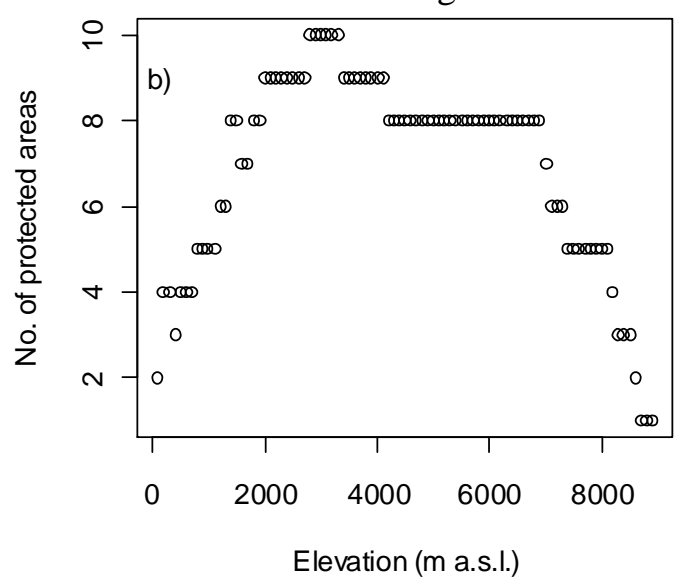

Figure 3b. Distribution of number of protected areas with elevation in Nepal.

\section{Medicinal orchid vs protected areas}

There are nine national parks, three wildlife reserves, one hunting reserve and three conservation areas and nine buffer zones covering $19.7 \%$ land of Nepal (GoN/MFSC, 2009). These protected areas are distributed from 75 to 8848 msl. Maximum number of protected areas is found at about 3000 to $3500 \mathrm{msl}$. The number of protected areas increases up to $3000 \mathrm{~m}$ and then gradually decreases after $3500 \mathrm{msl}$. There is a negative correlation between total number of medicinal orchids and number of protected areas $(\mathrm{r}=-0.216)$ (Fig. 4).

Large numbers of medicinal plants and orchids in wild are depleting due to mismanagement in the collection and/or unsustainable harvesting procedures that has been leading plants towards extinction from natural habitat. For example, one endemic species Pleione coronaria known from 
Ganesh Himal, Center Nepal, is highly threatened due to local deforestation (Winkel, 2006) and also medicinal orchids are generally uprooted as tubers are of medicinal value than other parts of plants. Tree felling for timber is causing significant mechanical damage to the biodiversity, especially the epiphytic orchids (Chaudhary, 2000). To protect from loss of species from

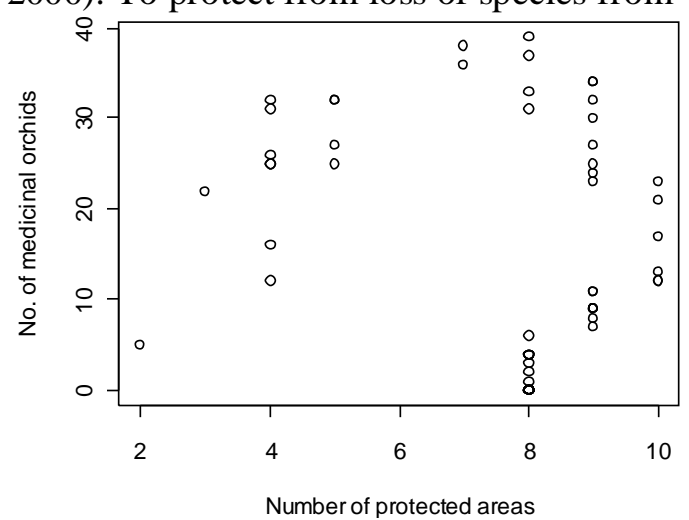

Figure 4. Scatter plot showing the relationship between number of medicinal orchids and number of protected areas of Nepal.

natural habitat, Government of Nepal has banned on collection of some species and their transportation. More over, as Nepal is the member country of CITES, The Convention on International Trade in Endangered species of Wild Fauna and Flora, since 1973 there is restriction in the collection and trade of all species of orchid under CITES Appendix II (Chaudhary, 1998). However, this type of ban and protection is not effective in the conservation of species as well as cannot reduce the volume of collection due to the fact that large part of the country is remote, people are illiterate and there is lack of specific understanding of government rules and regulations. There is also the report of some orchid species being sold even in open markets of Kathmandu (Acharya and Rokaya, 2005) which obviously shows that there is depletion of orchid population in the forest due the trade.

Protected areas can play a major role in protection of biodiversity because within these areas there is a restriction of collection of these species (Sharma et al., 2004). In the case of medicinal orchid species, there is negative correlation between number of protected areas and number of medicinal orchid species (Fig. 4). Maximum numbers of protected areas are found at about 3000 to $3500 \mathrm{msl}$. But, diversity of maximum number of medicinal orchids is found below this elevational range. This shows that our conservation efforts are less focused towards orchids. Protected areas are located at higher elevations where diversity of plants is less (Hunter and Yunzon, 1993). Along with this, there is no complete checklist of orchids distributed in each protected areas. Recently Government of Nepal made an official notice that orchids can be collected and sold. However, there needs the resource inventory form district forest office and should be approved by department of forest. According to this, all orchids (endemic, threatened, endangered and commonly available) are placed under same common name "Jiwanti" (locally known as "sungava") and there is no specialist to identify these orchids (per. com. with officer at department of forest). If the species is distributed across a large number of middle hill districts, collection and trade of these species is too high from lowland districts or Terai districts (Olsen, 2005). If this situation of collection continues, then large number of medicinal orchids will be threatened from low belts where the 
diversity is high. Another reason of higher collection from low belts is these areas are easily accessible and are densely populated by human beings.

In order to have sustainable management of orchids, Government of Nepal has given priority on domestication, research and cultivation of species. Some private nurseries are propagating large number of orchid species for sell. If these activities are run in different parts of rural areas, it will help to raise the economic status of poor. One of the successful community conservation programs, the community forest program, can help to produce wide range useful medicinal plants and orchids as projects under this program are at grass root level.

\section{Conclusion}

Nepal is rich in medicinal orchids which are generally terrestrial or epiphytic in habitat. There is an uneven distribution of medicinal orchids in horizontal or vertical manner of distribution. The highest numbers of orchids are found in central part of Nepal in horizontal manner whereas vertically maximum richness of medicinal orchid species is observed at an elevation of 1700 msl. As there is a threat to orchid populations due to human caused activities and also there is a vague knowledge about the available populations of orchids, it is necessary to carry out extensive field research to prioritize the conservation needs of such sites in the future. Further, in order to protect medicinal orchid diversity, it is necessary to establish protected areas and also synchronize between protected areas and orchid rich areas in Nepal.

\section{Acknowledgement}

Special thank to R.M. Kunwar for providing some relevant literature.

\section{References}

Acharya K.P. and M.B. Rokaya 2005. Ethnobotanical survey of medicinal plants traded in the streets of Kathmandu valley. Sci. World 3: 44-48.

Acharya, K.P. 2008. Orchid species richness along a Himalayan elevation gradient. Department of Biology, Faculty of Mathematics and Natural Sciences, University of Bergen, Bergen. (M.S. Thesis)

Acharya, K.P., R.P. Chaudhary and O.R. Vetaas 2009. Medicinal plants of Nepal: Distribution pattern along an elevational gradient and effectiveness of existing protected areas for their conservation. Banko Jankari 19(1): 16-22.

Bajracharya, D.M., A. Subedi and K.K. Shrestha 2003. Eria pokharensis sp nov (Orchidaceae): A new species from Nepal Himalaya. $J$. Orchid Soc., India. 17: 1-4.

Baral, S.R. and P.P. Khurmi 2006. A compendium of medicinal plants in Nepal. Mrs. Rachana Sharma, Kathmandu, Nepal.

Bhattarai, K.R. and O.R. Vetaas 2003. Variation of plant species richness of different life forms along a subtropical elevation gradient in the Himalayas, east Nepal. Glob. Ecol. Biogeography 12: 327-340.

Bulpitt, C.J. 2005. The uses and misuses of orchids in medicine. QJM: An Intern. J. Medicine 98: 625-631.

Chaudhary, R.P. 1998. Biodiversity in Nepal (Status and Conservation). S. Devi, Saharanpur (U.P.), India and Tecpress Books, Bangkok, Thailand.

Chaudhary, R.P. 2000. Forest conservation and environmental management in Nepal: a review. Biod. Conser. 9: 1235-1260.

Crawley, M.J. 2005. Statistics: an introduction using $R$. John Wiley and Sons Ltd., England.

DPR 2007. Bulletin of the Department of Plant Resources No. 28 Medicinal plants of Nepal (Revised). Department of Plant Resources, Ministry of Forest and Soil Conservation, Government of Nepal, Thapathali, Kathmandu, Nepal. 


\section{K.P. Acharya and M.B. Rokaya / Our Nature (2010) 8: 82-91}

Dressler, R.L. 1993. Phylogeny and classification of the orchid family. Dioscorides, Press, Portland.

GoN/MFSC 2009. Nepal fourth national report to the convention on biological diversity. Government of Nepal, Ministry of Forest and Soil Conservation, Kathmandu, Nepal.

Grytnes, J.A. 2003. Species-richness patterns of vascular plants along seven altitudinal transects in Norway. Ecography 26: 291-300.

Hastie, T.J. and R.J. Tibshirani 1990. Generalized additive models. Champman and Hall, London.

Hunter, M.L. and P. Yonzon 1993. Altitudinal distributions of birds, mammals, people, forests and parks in Nepal. Conser. Biol. 7: 420-423.

IUCN 2004. National register of medicinal and aromatic plants (Revised and updated). IUCNThe World Conservation Union, Nepal. $\mathrm{xii}+202 \mathrm{p}$.

Jacquemyn, H., C. Micheneau, D.L. Roberts and T. Pailler 2005. Elevational gradients of species diversity, breeding system and floral traits of orchid species on Réunion Island. $J$. Biogeography 32: 1751-1761.

Jha, P.K., K.K. Shrestha, M.P. Upadhyay, D.P. Stimart and D.M. Spooner 1996. Plant genetic resources of Nepal: a guide for plant breeders of agriculture, horticultural and forestry crops. Euphytica 87: 189-210.

Lama, Y.C., S.K. Ghimire and Y. AumeeruddyThomas 2001. Medicinal plants of Dolpo: Amchis' knowledge and conservation. WWF Nepal Program, Kathmandu.

LRMP 1986. Land system report. Land Resource Mapping Project, HMG/N and Government of Canada, Kathmandu, Nepal.

Malla, S.B. and P.R. Shakya 1999. Medicinal plants. In Nepal Nature's Paradise (Eds. T.C. Majupuria and R.K. Majupuria). M. Devi, Gwalior, India. pp. 261-297.

Manandhar, N.P. 2002. Plants and people of Nepal. Timber Press Portland, Oregon, USA.

O’Brien, E.M. 1998. Water-energy dynamics, climate and prediction of woody plant species richness, an interim general model. J. Biogeography 25: 379-398.
Odland, A. and H.J.B. Birks 1999. The altitudinal gradient of vascular plant richness in Aurland, western Norway. Ecography 22: 548-566.

Olsen, C.S. 2005. Valuation of commercial central Himalayan medicinal plants. Ambio. 34: 607610.

Pengelly, A. 2004. The constituents of medicinal plants: an introduction to the chemistry and therapeutics of herbal medicine. Sunflower herbals, $2^{\text {nd }}$ Edition. $184 \mathrm{p}$.

$\mathrm{R}$ Development Core Team 2008. R: a language and environment for statistical computing. $\mathrm{R}$ Foundation for Statistical Computing, Vienna.

Rajbhandari, K.R. and S. Dahal 2004. Orchids of Nepal: a checklist. Bot. Orient. 4: 89-106.

Rajbhandari, K.R. 2001. Ethnobotany of Nepal. Ethnobotanical Society of Nepal, Kathmandu, Nepal.

Rajbhandari, K.R., S. Bhattarai and R. Joshi 2000. Orchid diversity of Nepal and their conservation need. In Proceedings of $8^{\text {th }}$ International Workshop of BIO-REFOR: Biotechnology applications for reforestation and biodiversity conservation (Kathmandu) Nepal. pp. 249-252.

Rokaya, M.B. 2002. Ethnoecology of medicinal plants in Dho-Tarap area in buffer zone of Shey Phoksundo National Park, Dolpa, Nepal. Central Department of Botany, Tribhuvan University, Kirtipur. (M.Sc. Thesis)

Shakya, L.R. and M.R. Shrestha 2007. Two new taxa of orchidaceae from central Nepal. Edinb. J. Bot. 64: 1-5.

Shakya, L.R. and R.P. Chaudhary 1999. Taxonomy of Oberonia rufilabris (Orchidaceae) and allied new species from the Himalaya. Harvard Paper Bot. 4: 357-363.

Sharma, D.K. 2000. Distribution of medicinal plants in Ilam district of Nepal. In The Himalayan plants, can they save us? Proceeding of NepalJapan joint symposium on conservation and utilization of Himalayan medicinal resources (Eds. T. Watanabe, A. Takano, M.S. Bista and H.K. Saiju), Society for the Conservation and Development of Himalayan Medicinal Resources (SCDHMR), Japan. pp. 192-197. 


\section{K.P. Acharya and M.B. Rokaya / Our Nature (2010) 8: 82-91}

Sharma, U.R., K.J. Malla and R.K. Uprety 2004. Conservation and management efforts of medicinal and aromatic plants in Nepal. Banko Jankari 14(2): 3-11.

Shmida, A. and M.W. Wilson 1985. Biological determinants of species diversity. $J$. Biogeography 12: 1-20.

Shrestha, M.R., L.R. Shakya and S.K. Ghimire 2007. A new species of Malaxis solander ex Swartz (Orchidaceae) from Dolpa, Nepal. Pleione 1: 6-7.

Shrestha, R. 2000. Some medicinal orchids of Nepal. In The Himalayan plants, can they save us? Proceeding of Nepal-Japan joint symposium on conservation and utilization of Himalayan medicinal resources (Eds. T. Watanabe, A. Takano, M.S. Bista and H.K. Saiju), Society for the Conservation and Development of Himalayan Medicinal Resources (SCDHMR), Japan. pp. 153-156.
Subedi, A. 2003. Orchid flora of Seti and Marsyangdi river valleys of central Nepal. Central Department of Botany, Tribhuvan Univeristy, Kirtipur. (M.Sc. Thesis)

Sumner, J. 2000. The natural history of medicinal plants. Timber Press, Oregon, USA.

Vaidya, B., M. Shrestha and N. Joshee 2000. Report on Nepalese orchid species with medicinal properties. In The Himalayan plants, can they save us? Proceeding of Nepal-Japan joint symposium on conservation and utilization of Himalayan medicinal resources (Eds. T. Watanabe, A. Takano, M.S. Bista and H.K. Saiju), Society for the Conservation and Development of Himalayan Medicinal Resources (SCDHMR), Japan. pp. 146-152.

Winkel, G.V. 2006. Finding orchids in Nepal. The Orchid Rev. 114: 188-191.

\section{Appendix I}

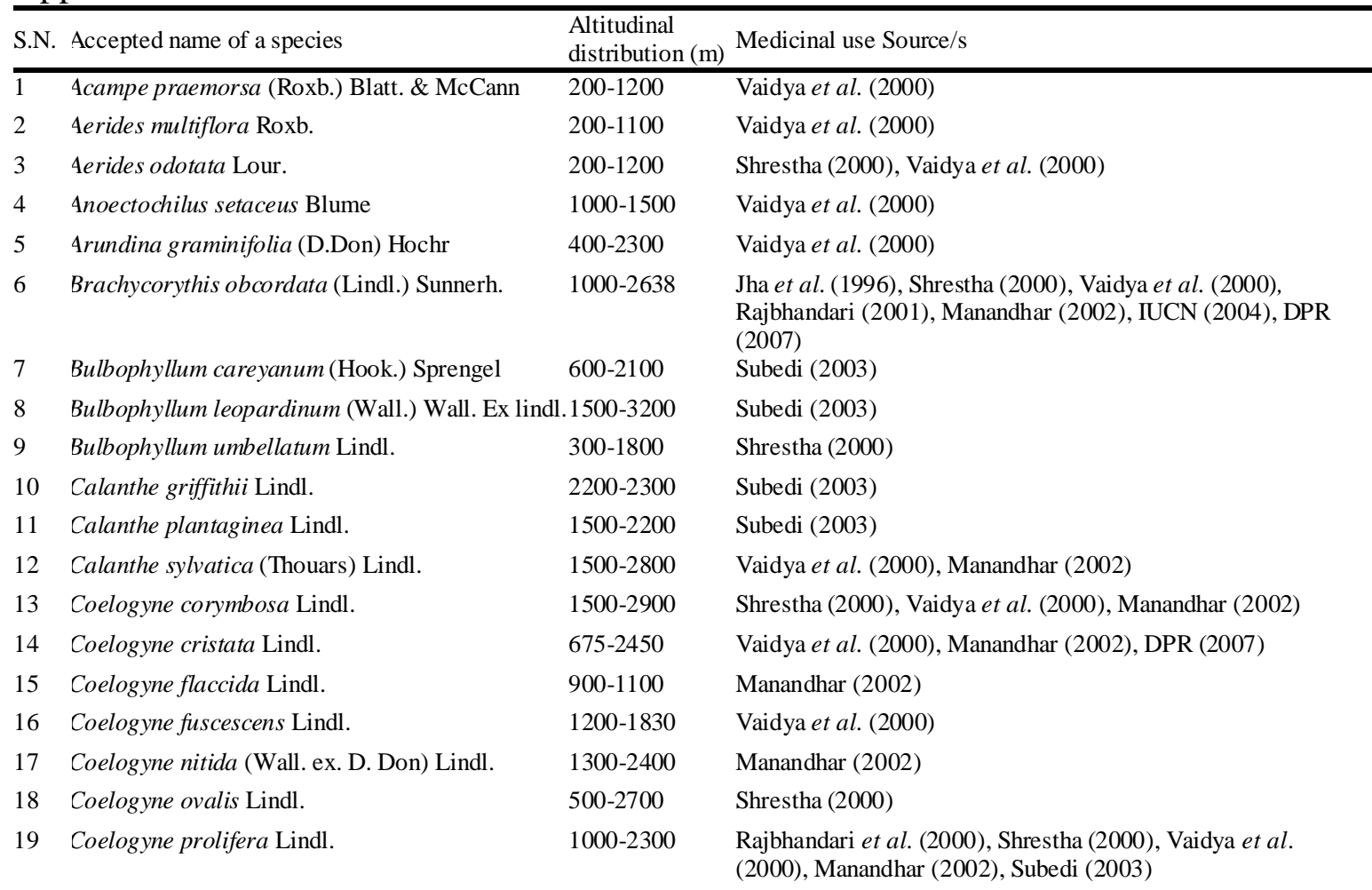


K.P. Acharya and M.B. Rokaya / Our Nature (2010) 8: 82-91

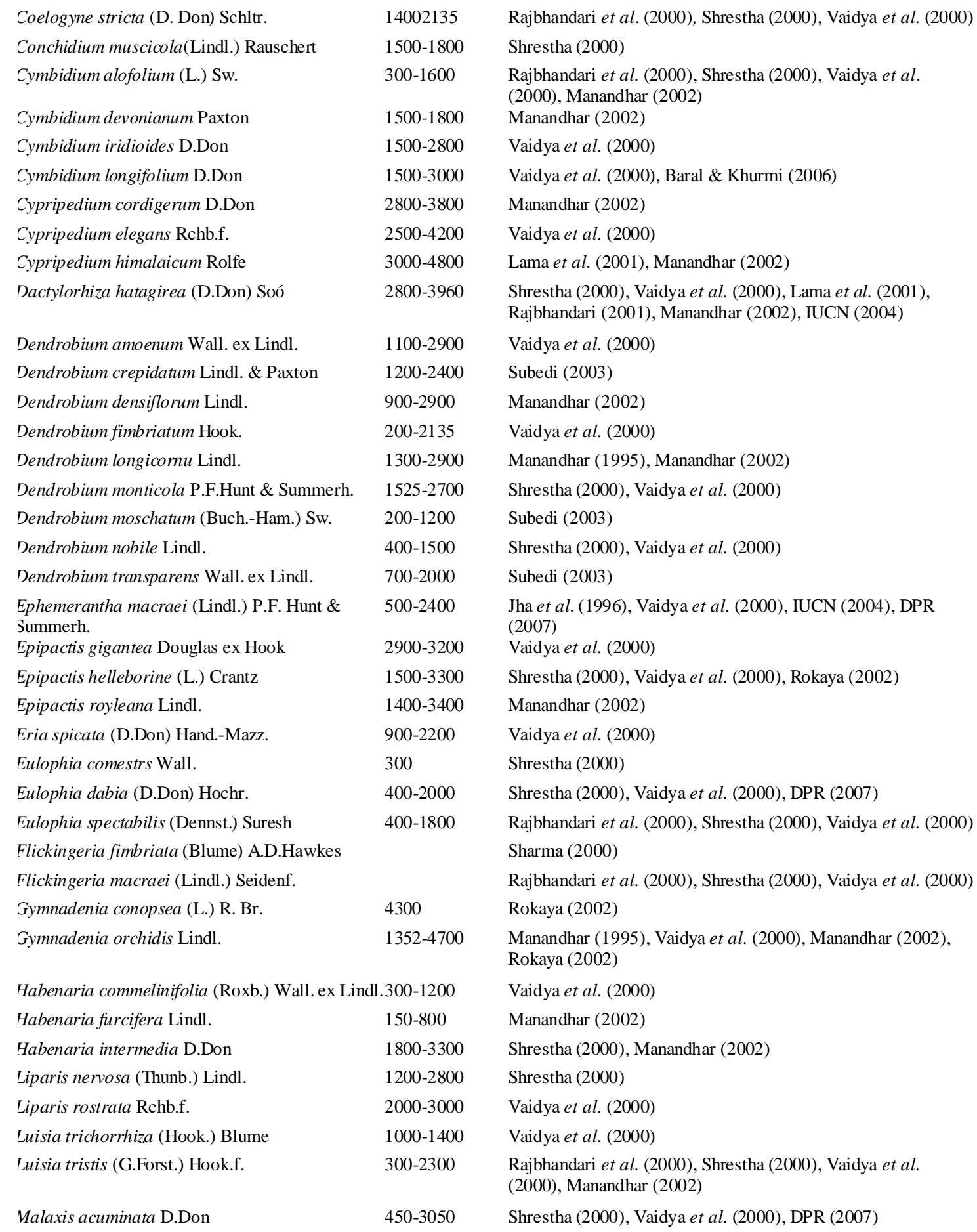


K.P. Acharya and M.B. Rokaya / Our Nature (2010) 8: 82-91

Malaxis cylindrostachya (Lindl.) Kuntze

Malaxis muscifera (Lindl.) Kuntze

Vervilia aragoana Gaudich.

Oberonia caulescens Lindl.

Orchis latifolia Linn.*

Otochilus porrectus Lindl.

Papilionanthe teres (Roxb.) Schltr.

Pholidota articulata Lindl.

Pholidota imbricata Lindl.

Platanthera sikkimensis (Hook.f.) Kraenzl.

Pleione humilis (Sm.) D.Don

Pleione maculata (Lindl.) Lindl. \& Paxton

Pleione praecox (Sm.) D.Don

Ponerorchis chusua (D.Don) Soó

Rhynchostylis retusa (L.) Blume

Satyrium nepalense D.Don

Smitinandia micrantha (Lindl.) Holttum

Spiranthes sinensis (Pers.) Ames

Thunia alba (Lindl.) Rchb.f.

Trudelia praviflora*

Vanda cristata Wall. ex Lindl.

Vanda tessellata (Roxb.) Hook. ex G.Don

Vanda testacea (Lindl.) Rchb.f.

Zeuxine strateumatica (L.) Schltr.

\begin{tabular}{|c|c|}
\hline $2100-3500$ & Manandhar (2002) \\
\hline $2000-4100$ & DPR (2007) \\
\hline $500-1300$ & Vaidya et al. (2000), DPR (2007) \\
\hline \multirow[t]{2}{*}{$1300-2400$} & Vaidya et al. (2000) \\
\hline & Sharma (2000) \\
\hline $900-2300$ & IUCN (2004) \\
\hline $200-2100$ & Manandhar (2002) \\
\hline $570-2285$ & Vaidya et al. (2000), Manandhar (2002) \\
\hline $600-2900$ & $\begin{array}{l}\text { Rajbhandari et al. (2000), Shrestha (2000), Vaidya et al. } \\
\text { (2000), Manandhar (2002) }\end{array}$ \\
\hline $2600-2900$ & Shrestha (2000), Vaidya et al. (2000) \\
\hline $1800-3000$ & Manandhar (2002) \\
\hline $1400-2700$ & Shrestha (2000), Vaidya et al. (2000) \\
\hline $1500-2500$ & Rajbhandari (2001), Manandhar (2002) \\
\hline $2400-4900$ & Rokaya (2002) \\
\hline $300-1850$ & $\begin{array}{l}\text { Shrestha (2000), Vaidya et al. (2000), Manandhar (2002), DPR } \\
\text { (2007) }\end{array}$ \\
\hline $600-4600$ & Shrestha (2000), Vaidya et al. (2000) \\
\hline $500-1400$ & Vaidya et al. (2000), Rajbhandari (2001), Manandhar (2002) \\
\hline $150-4600$ & Shrestha (2000), Vaidya et al. (2000) Rokaya (2002) \\
\hline $500-1800$ & Manandhar (2002) \\
\hline $350-915$ & Vaidya et al. (2000) \\
\hline $620-2300$ & Vaidya et al. (2000), Rajbhandari (2001), Manandhar (2002) \\
\hline $200-600$ & Rajbhandari et al. (2000), Shrestha (2000), Vaidya et al. (2000) \\
\hline 460 & Vaidya et al. (2000) \\
\hline $230-1220$ & Shrestha (2000), Vaidya et al. (2000) \\
\hline
\end{tabular}

